\title{
The Effect of Improvement in Diabetic Control on Plasma and Whole Blood Viscosity
}

\author{
R. B. Paisey ${ }^{1}$, J. Harkness ${ }^{2}$, M. Hartog ${ }^{1}$, and T. Chadwick ${ }^{1}$ \\ ${ }^{1}$ University Department of Medicine, Bristol Royal Infirmary, Bristol, and ${ }^{2}$ Department of Chemical Pathology, \\ Musgrove Park Hospital, Taunton, Somerset, England
}

Summary. Rheological studies were made on the blood of 12 diabetic patients after a period of poor diabetic control $\left(\mathrm{HbA}_{1} 12.6 \pm 0.7 \%\right.$ (mean $\pm \mathrm{SD}$ ); mean home capillary blood glucose level $11.7 \pm$ $1.2 \mathrm{mmol} / \mathrm{l}$ ), and after at least three months of improved control $\left(\mathrm{HbA}_{1} 9.1 \pm 0.4 \%, \mathrm{p}<0.01\right.$; mean home capillary blood glucose level $9.2 \pm$ $0.6 \mathrm{mmol} / \mathrm{l})$. There were significant decreases in plasma fibrinogen levels $(4.1 \pm 0.6$ to $3.7 \pm 0.6 \mathrm{~g} / \mathrm{l}, \mathrm{p}$ $<0.01)$, plasma viscosity $(1.31 \pm 0.1$ to $1.25 \pm 0.04$, $\mathrm{p}<0.001)$, and whole blood viscosity at low $(22.8 \pm$ 2.7 to $20.2 \pm 2.9, \mathrm{p}<0.01)$ and high shear rates $(3.4$ \pm 0.2 to $3.1 \pm 0.2, \mathrm{p}<0.01$ ). Ten diabetics with clinically evident complications were matched with diabetics of similar age, sex, duration and current control of diabetes. There were no significant differences in plasma or whole blood viscosities between the two groups. Hyperviscosity in diabetes seems strongly related to hyperglycaemia and to be influenced by the quality of diabetic control.

Key words: Rheology, plasma fibrinogen level, plasma viscosity, whole blood viscosity, shear rate, Contraves rotational viscometer, glycosylated haemoglobin.

There is evidence that diabetics have higher than normal plasma and whole blood viscosity $[1,2,3]$, and it has been reported that diabetics with complications have higher viscosities than those with no complications $[4,5]$. There have been suggestions that hyperviscosity might contribute to the development of vascular disease in diabetics, as in the retinopathy of the dysgammaglobulinaemias $[6,7,8,9]$. The present study was undertaken to see whether improve- ment in diabetic control affects blood viscosity, and whether patients with diabetic complications have higher viscosities than matched diabetics with no complications, but a similar degree of recent hyperglycaemia.

\section{Patients and Methods}

\section{Patients}

Twelve diabetics were studied for $8-12$ weeks and all gave informed consent to the study. Their characteristics are shown in Table 1.

Persistent poor control of blood glucose was shown by home blood glucose monitoring and measurement of glycosylated haemoglobin $\left(\mathrm{HbA}_{1}\right)$. Improvement was achieved by changing four patients from once to twice daily insulin regimes, two from Actrapid and Semitard to Actrapid and Monotard, and just increasing the insulin dose in a further five patients. In one patient (Number 6, Table 1), hyperglycaemia was reduced by increasing his dose of glibenclamide. Rheological measurements were performed after both periods of study.

Ten diabetics with clinically apparent complications (always including retinopathy) were matched for age, sex, treatment, current control and duration of diabetes, with ten diabetics without clinical evidence of complications. Characteristics of all twenty are given in Table 2.

\section{Laboratory Methods}

Home capillary blood glucose levels were measured pre and postprandially by a method previously described (10) to give 7-8 samples in $24 \mathrm{~h}$ every $2-4$ weeks. $\mathrm{HbA}_{1}$ was measured by Quik-sep column (normal range 6-8\%, coefficient of variation (CV) $4.5 \%$ ). Plasma fibrinogen levels were measured on immuno-diffusion plates (Hoechst), normal range $2.5-4.0 \mathrm{~g} / \mathrm{l}$, (CV 10\%). Plasma viscosity was measured at $37^{\circ} \mathrm{C}$ by capillary Viscometer (normal range 1.16-1.35 centipoise, CV 3\%). Whole blood viscosity was measured both at high shear rate $\left(1000 \mathrm{sec}^{-1}\right)$ with the capillary viscometer (normal range 2.5-3.8 centipoise, CV 3.4\%) and at low shear rate $\left(1 \mathrm{sec}^{-1}\right)$ with the Contraves rotational viscometer (normal range 15-23 centipoise if samples initially adjusted to PCV $45 \%$, CV $5 \%$ ). 
Table 1. Characteristics of patients in the study of improved diabetic control and viscosity. Patients were studied before and after changes in insulin treatment or increase in sulphonylurea. All patients were within $10 \%$ of ideal body weight

\begin{tabular}{|c|c|c|c|c|c|c|c|c|c|c|c|c|c|c|}
\hline \multirow[t]{2}{*}{ Patient } & \multirow[t]{2}{*}{ Age } & \multirow[t]{2}{*}{ Sex } & \multirow{2}{*}{$\begin{array}{l}\text { Initial } \\
\text { body } \\
\text { weight } \\
\text { (kg) }\end{array}$} & \multirow{2}{*}{$\begin{array}{l}\text { Dura- } \\
\text { tion } \\
\text { (years) }\end{array}$} & \multicolumn{5}{|c|}{ Poor control } & \multicolumn{5}{|c|}{ Improved control } \\
\hline & & & & & $\begin{array}{l}\text { Mean } \\
\text { blood } \\
\text { glucose } \\
(\mathrm{mmol} / \mathrm{l})\end{array}$ & $\begin{array}{l}\mathrm{HbA}_{1} \\
\%\end{array}$ & $\begin{array}{l}\text { T.G. } \\
(\mathrm{mmol} / \mathrm{l}\end{array}$ & $\begin{array}{l}\text { Cholesterol } \\
\text { (mmol/l) }\end{array}$ & $\begin{array}{l}\text { HCT } \\
\%\end{array}$ & $\begin{array}{l}\text { Mean } \\
\text { blood } \\
\text { glucose } \\
\text { (mmol/1) }\end{array}$ & $\begin{array}{l}\mathrm{HbA}_{1} \\
\%\end{array}$ & $\begin{array}{l}\text { T.G. } \\
(\mathrm{mmol} / \mathrm{I})\end{array}$ & $\begin{array}{l}\text { Cholesterol } \\
\text { l) }(\mathrm{mmol} / \mathrm{l})\end{array}$ & $\begin{array}{l}\mathrm{HCT} \\
\%\end{array}$ \\
\hline 1 & 35 & M & 69.0 & 29 & 18.0 & 18.8 & - & - & 42 & 10.9 & 7.8 & - & - & 44 \\
\hline 2 & 22 & $\mathrm{~F}$ & 58.5 & 16 & 15.9 & 15.4 & 2.0 & 7.9 & 48 & 12.0 & 11.2 & 1.8 & 4.9 & 43 \\
\hline 3 & 42 & $\mathrm{M}$ & 71.3 & 4 & 9.6 & 11.0 & 1.1 & 4.2 & 45 & 6.5 & 6.3 & 0.9 & 4.6 & 45 \\
\hline 4 & 24 & $\mathrm{~F}$ & 59.6 & 5 & 9.6 & 11.6 & 1.3 & 5.8 & 47 & 7.7 & 8.7 & 1.2 & 5.6 & 45 \\
\hline 5 & 23 & $\mathrm{M}$ & 71.4 & 5 & 8.2 & 9.7 & 1.1 & 3.9 & 50 & 6.0 & 8.0 & 1.1 & 3.2 & 49 \\
\hline 6 & 40 & M & 68.1 & 5 & 11.5 & 12.9 & - & - & 50 & 9.8 & 10.3 & - & - & 50 \\
\hline 7 & 40 & M & 71.9 & 2 & 10.3 & 11.5 & 0.7 & 4.3 & 47 & 8.3 & 8.9 & 0.6 & 4.4 & 42 \\
\hline 8 & 56 & $\mathrm{~F}$ & 59.8 & 10 & 9.6 & 9.4 & 0.7 & 6.7 & 45 & 7.6 & 7.4 & 0.6 & 7.2 & 46 \\
\hline 9 & 29 & $\mathrm{M}$ & 68.5 & 7 & 12.8 & 14.0 & 1.1 & 5.4 & 49 & 11.0 & 10.4 & 1.0 & 5.3 & 49 \\
\hline 10 & 18 & $F$ & 50.0 & 2 & 13.3 & 12.7 & - & - & 43 & 12.5 & 11.2 & - & - & 42 \\
\hline 11 & 36 & $\mathrm{M}$ & 70.1 & 2 & 10.0 & 11.4 & 1.0 & 5.3 & 47 & 8.4 & 9.4 & 0.9 & 5.0 & 47 \\
\hline 12 & 54 & $\mathrm{~F}$ & 61.5 & 8 & 11.0 & 11.8 & - & - & 40 & 9.5 & 10.0 & - & - & 42 \\
\hline $\begin{array}{l}\text { Mean } \\
\pm \text { SEM }\end{array}$ & $\begin{array}{l}35.0 \\
\pm 3.6\end{array}$ & & & $\begin{array}{l}7.9 \\
\pm 2.2\end{array}$ & $\begin{array}{l}11.7^{\mathrm{a}} \\
\pm 1.19\end{array}$ & $\begin{array}{l}12.6^{\mathrm{b}} \\
\pm 0.7\end{array}$ & $\begin{array}{l}1.10 \\
\pm 0.1\end{array}$ & $\begin{array}{l}5.4 \\
\pm 0.5\end{array}$ & $\begin{array}{l}46.1 \\
\pm 0.9\end{array}$ & $\begin{array}{l}9.2^{\mathrm{a}} \\
\pm 0.6\end{array}$ & $\begin{array}{l}9.1^{b} \\
\pm 0.4\end{array}$ & $\begin{array}{l}1.0 \\
\pm 0.1\end{array}$ & $\begin{array}{l}5.0 \\
\pm 0.4\end{array}$ & $\begin{array}{l}45.5 \\
\pm 0.81\end{array}$ \\
\hline
\end{tabular}

a Difference significant at $5 \%$ level

b T.G., serum triglyceride; HCT, haematocrit

Difference significant at $1 \%$ level - paired t test

Table 2. Characteristics of matched patients with and without complications of diabetes

\begin{tabular}{|c|c|c|c|c|c|c|c|c|c|c|c|c|c|}
\hline \multicolumn{7}{|c|}{ Patients with complications } & \multicolumn{7}{|c|}{ Matched patients free from complications } \\
\hline Patient & Age & Sex & $\begin{array}{l}\text { Dura- } \\
\text { tion } \\
\text { (years) }\end{array}$ & $\begin{array}{l}\text { Treat- } \\
\text { ment }\end{array}$ & $\begin{array}{l}\text { Mean } \\
\text { blood } \\
\text { glucose } \\
(\mathrm{mmol} / \mathrm{l})\end{array}$ & $\begin{array}{l}\mathrm{Hb}_{\%} \\
\%\end{array}$ & Patient & Age & Sex & $\begin{array}{l}\text { Dura- } \\
\text { tion } \\
\text { (years) }\end{array}$ & $\begin{array}{l}\text { Treat- } \\
\text { ment }\end{array}$ & $\begin{array}{l}\text { Mean } \\
\text { blood } \\
\text { glucose } \\
(\mathrm{mmol} / \mathrm{l})\end{array}$ & $\begin{array}{l}\mathrm{HbA}_{1} \\
\%\end{array}$ \\
\hline 13 & 63 & $\mathrm{~F}$ & 10 & Glipizide & 12.3 & 13.9 & 23 & 68 & $\mathrm{~F}$ & 6 & Glizipide & 12.9 & 12.1 \\
\hline 14 & 64 & $\mathrm{M}$ & 2 & Gliben. & 8.7 & 9.6 & 24 & 63 & M & 6 & Gliben. & 9.0 & 10.7 \\
\hline 15 & 58 & $\mathrm{~F}$ & $1 \overline{5}$ & Insulin & 6.4 & 6.3 & 25 & 56 & $\mathrm{~F}$ & 10 & Insulin & 7.3 & 7.6 \\
\hline 16 & 51 & M & 10 & Glipizide & 6.0 & 6.5 & 26 & 55 & M & 10 & Glipizide & 6.4 & 7.6 \\
\hline 17 & 22 & $\mathrm{~F}$ & 16 & Insulin & 12.0 & 14.0 & 27 & 25 & $F$ & 12 & Insulin & 12.0 & 13.5 \\
\hline 18 & 34 & M & 29 & Insulin & 8.0 & 7.8 & 28 & 30 & M & 21 & Insulin & 11.0 & 10.6 \\
\hline 19 & 50 & $\mathrm{~F}$ & 23 & Insulin & 12.0 & 11.8 & 29 & 54 & $\mathrm{~F}$ & 21 & Insulin & 11.5 & 11.8 \\
\hline 20 & 48 & $\mathrm{~F}$ & 17 & Insulin & 11.4 & 11.9 & 30 & 46 & $F$ & 15 & Insulin & 10.0 & 10.4 \\
\hline 21 & 50 & $\mathrm{M}$ & 8 & Insulin & 9.0 & 8.9 & 31 & 57 & M & 10 & Insulin & 9.5 & 10.1 \\
\hline 22 & 62 & $\mathrm{~F}$ & 6 & Insulin & 5.5 & 6.4 & 32 & 50 & F & 8 & Insulin & 6.0 & 7.8 \\
\hline $\begin{array}{l}\text { Mean } \\
\pm \text { Sem }\end{array}$ & $\begin{array}{l}51.2 \\
\pm 4.3\end{array}$ & & $\begin{array}{l}13.6 \\
\pm 2.4\end{array}$ & & $\begin{array}{c}9.1 \\
\pm 0.8\end{array}$ & $\begin{array}{c}9.7 \\
\pm 1.0\end{array}$ & & $\begin{array}{l}50.4 \\
\pm 4.1\end{array}$ & & $\begin{array}{l}11.7 \\
\pm 1.5\end{array}$ & & $\begin{array}{c}9.6 \\
\pm 0.8\end{array}$ & $\begin{array}{l}10.2 \\
\pm 0.6\end{array}$ \\
\hline
\end{tabular}

All patients were within $10 \%$ of ideal body weight

Glipizide - before meals

Gliben. - Glibenclamide twice daily

\section{Collection and Transport of Samples}

All samples were taken between 0930 and $1100 \mathrm{~h}$. Sequestrene (EDTA) samples were gently inverted 15 times then placed immediately on ice, and kept at $4^{\circ} \mathrm{C}$ during transport from Bristol to Taunton where viscosity measurements were performed
22-24 $\mathrm{h}$ afterwards at $37^{\circ} \mathrm{C}$. To establish the validity of measurements after this procedure ten blood samples were tested for whole blood viscosity both before and after $24 \mathrm{~h}$ storage at $4^{\circ} \mathrm{C}$. Results were as follows:- whole blood viscosity at high shear rate $3.31 \pm$ 0.4 centipoise when measured immediately, $3.31 \pm 0.4$ centipoise after $24 \mathrm{~h}$ at $4^{\circ} \mathrm{C}$; whole blood viscosity at $1 \mathrm{sec}^{-1} 20.7 \pm 4.3$ 

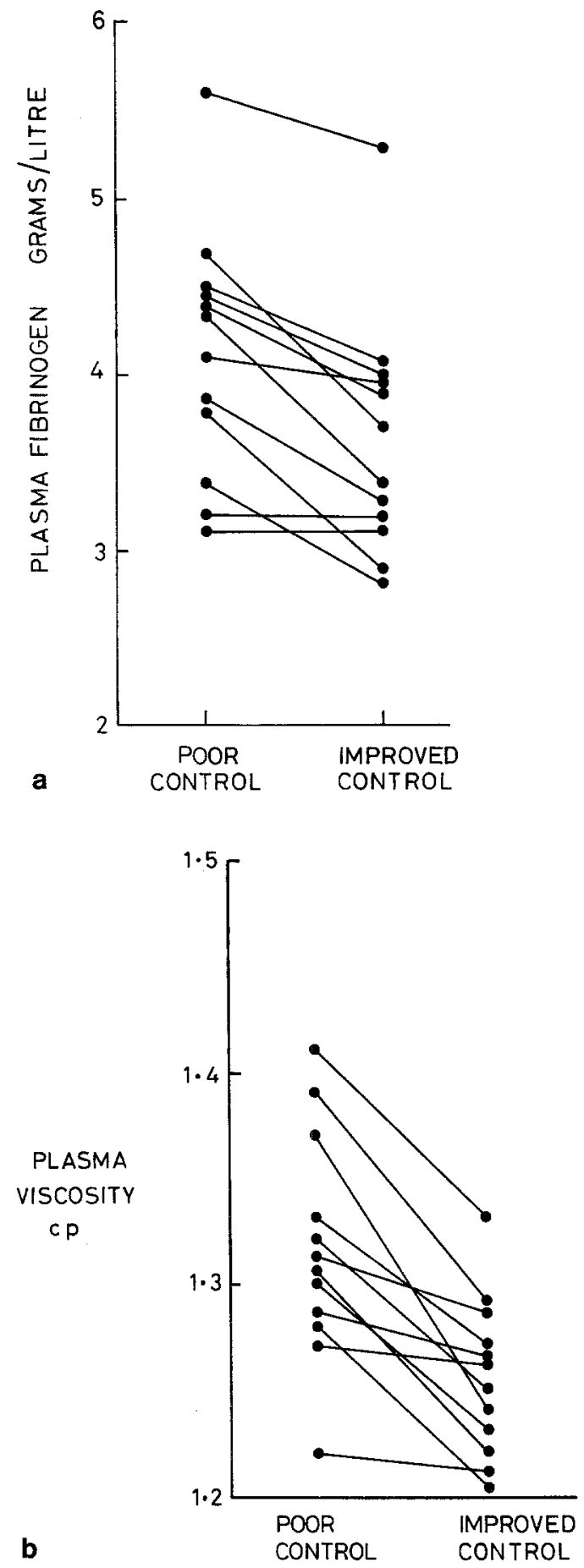
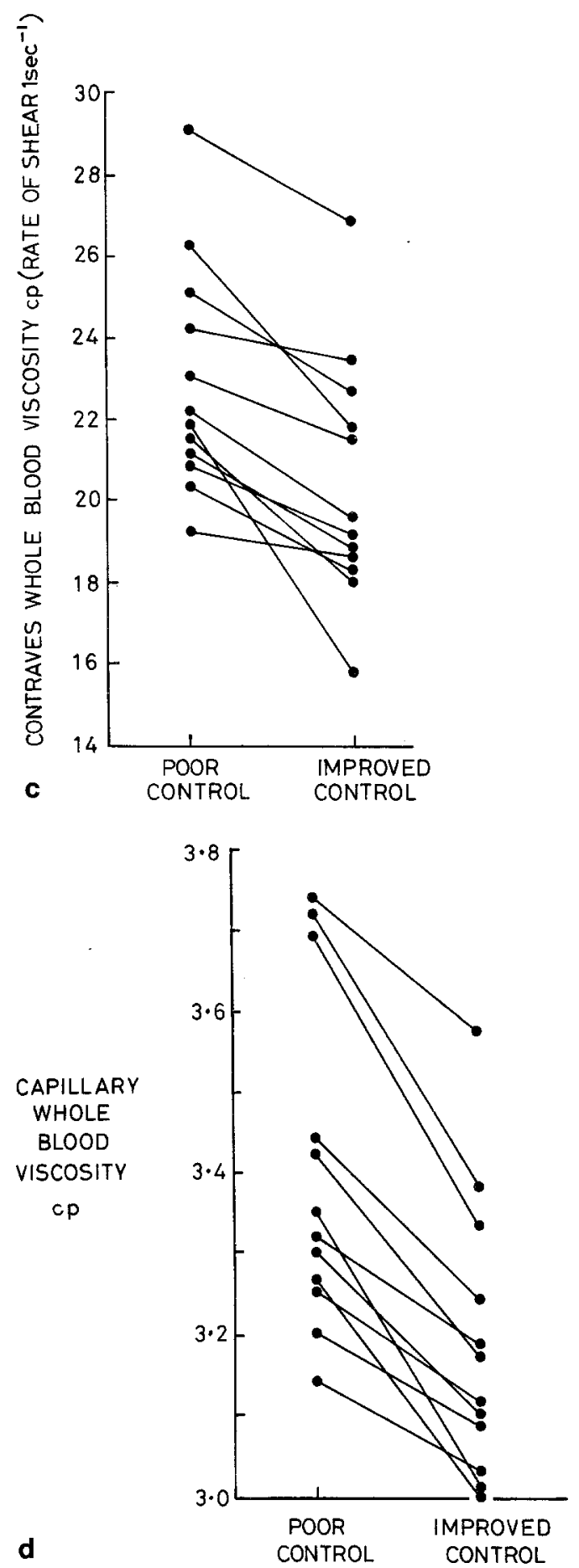

Fig. 1. Changes in plasma fibrinogen, plasma viscosity and whole blood viscosity at low and high shear rates after reduction of hyperglycaemia. Each pair of points represents one patient before and after improvement in glucose control. The scale has been expanded to emphasise these changes, but it is notable that all patients showed a fall in viscosity measurements, not only when made on blood corrected for $\mathrm{PCV}$ of $45 \%$ but also when tested before this correction

centipoise when measured immediately, $21.0 \pm 4.2$ centipoise after 24 hours at $4^{\circ} \mathrm{C}$. We have found whole blood viscosity to increase after storage of blood at room temperature as previously reported [11], but changes in red cells causing this increase are prevented for up to $24 \mathrm{~h}$ by storage at $4^{\circ} \mathrm{C}$.

Statistical analysis was performed using paired and unpaired $t$ tests. All results are given as mean $\pm \mathrm{SD}$ unless otherwise state.

\section{Results}

There was no consistent change in haematocrit or serum cholesterol after reduction in hyperglycaemia, though fasting triglyceride levels fell in all of the eight patients in whom this was measured. Figures $1 \mathrm{a}-\mathrm{d}$ 
show the corresponding reductions in plasma fibrinogen $(4.1 \pm 0.6$ to $3.7 \pm 0.6 \mathrm{~g} / \mathrm{l}, \mathrm{p}<0.01)$, plasma viscosity $(1.31 \pm 0.1$ to $1.25 \pm 0.04$ centipoise, $\mathrm{p}<$ $0.001)$, whole blood viscosity at low shear rate ( 22.8 \pm 2.7 to $20.2 \pm 2.8$ centipoise, $p<0.01$ ), and whole blood viscosity at high shear rate $(3.4 \pm 0.2$ to $3.1 \pm$ $0.2, \mathrm{p}<0.001$ ).

In contrast, the plasma fibrinogen levels and mean viscosities in 10 diabetics with complications were not significantly different from measurements in diabetics matched for age, sex, treatment, current control, and duration of diabetes. Results were as follows, fibrinogen levels $4.3 \pm 0.9$ and $4.1 \pm 0.8 \mathrm{~g} / \mathrm{l}$; plasma viscosities $1.4 \pm 0.1$ and $1.4 \pm 0.1$ centipoise; capillary whole blood viscosity at high shear rate 3.5 \pm 0.5 and $3.6 \pm 0.4$ centipoise; and whole blood viscosity at low shear rate $22.9 \pm 6.9$ and $23.4 \pm 3.1$ centipoise.

\section{Discussion}

In this study there was no consistent change in haematocrit after reduction of hyperglycaemia, though in a larger study, with greater changes in blood glucose levels, a fall in haematocrit might be expected. There is a relationship between haematocrit, plasma viscosity and whole blood viscosity [12, $13,14]$ and any such fall in haematocrit would accentuate the changes which we have found in whole blood viscosity. In our study it is most likely that improvement in diabetic glycaemic control has resulted in decreased whole blood viscosity as a consequence of decreased plasma viscosity, and that this has in turn resulted from the decrease in plasma fibrinogen. Changes in globulins may also have played a part but the small changes in fasting triglyceride levels found in eight patients seem unlikely to be relevant to blood viscosity changes. The high plasma fibrinogen levels when patients were more hyperglycaemic could have resulted from dehydration (reduction of plasma volume) an increase in hepatic synthesis of fibrinogen, or from a combination of the two. Serum globulins might be similarly raised, or their pattern disturbed $[4,15]$ by the effect of hyperglycaemia on hepatic synthesis. In addition, post translational glycosylation of many serum glycoproteins may occur in proportion to prevailing blood glucose levels [16] (analagous to the glycosylation of $\mathrm{HbA}$ ), and glycosylation of globulins could produce conformational molecular changes resulting in increased plasma viscosity.

Changes in red cell deformability were not measured in our study, though some changes have been described in diabetes $[17,18]$, and if hyperglycaemia decreased red cell deformability then this would have contributed to increased whole blood viscosity.

Whether changes in blood viscosity of the order seen in our patients could affect tissue perfusion, particularly in the retina, is not known, though experimental increases in blood viscosity have been shown to reduce retinal blood flow [19]. However, in our second group of patients there was no difference in rheological variables between those with extensive complications of diabetes and the matched patients without clinically apparent complications. Six of these patients had advancing retinopathy under current photocoagulation treatment and four of these (Numbers 16, 18, 21 and 22) had plasma and whole blood viscosities within the normal range. This suggests that hyperviscosity is at least not necessary for the continued worsening of retinopathy in some patients. If larger numbers had been studied, a significant increase in blood viscosity might have emerged in those patients with complications. However, all the patients in these matched groups had suffered from diabetes for at least six years and widespread vascular changes could well be present in the patients free from obvious clinical complications. This might affect blood viscosity resulting in overall increases in both patients with and without obvious retinopathy alike, because of the presence of large vessel disease $[5,18]$. There is some evidence that the threshold of hyperglycaemia associated with the development of macroangiopathy is lower than that for microvascular disease [20].

Lastly, the patients with complications and their matched controls had a mean duration of diabetes of 12.6 years, and a mean age of 51 years compared with 7.9 and 35 years respectively for patients in the study of diabetic control. These differences might well be associated with more widespread macroangiopathy in the patients with complications and their matched controls and this could have produced the higher blood viscosity levels found in these patients. These factors might also partly explain the increased whole blood viscosity in diabetics with retinopathy, compared with those with no retinopathy in a recent study [21], though these patients were not accurately matched for current glycaemic control of diabetes.

Acknowledgements. We would like to thank Mr David White and Mr Paul Bradshaw for technical assistance, the South West Regional Blood Transfusion Service for transport of samples, Miss Anne Brown for typing the manuscript, and the Department of Medical Illustration at Southmead Hospital, Bristol.

\section{References}

1. Skooborg F, Nielsen AA, Schlicktkrul J, Ditzel J (1967) Further studies of the blood viscosity in diabetic patients. Bibl Anat 9: 508 
2. Ditzel J (1968) Whole blood viscosity and related components. Dan Med Bull 15: 9-53

3. Bollinger A, Berchtold P, Berger W (1969) Untersuchungen der Blutviskosität bei Diabetikern. Praxis 58: 1104-1107

4. McMillan DE (1976) Plasma protein changes, blood viscosity and diabetic microangiopathy. Diabetes $25: 858-864$

5. Barnes AJ, Scudder PR, Dormandy TL, Dormandy JA, Slack J (1977) Is hyperviscosity a treatable component of diabetic microcirculatory disease? Lancet II : 789-794

6. Schwab PJ, Okun E, Fahey JL (1960) Reversal of retinopathy in Waldenström's macroglobulinaemia: plasmapheresis. Arch Opthalmol 64: 515-527

7. Rosen ES, Simmons AV, Warnes TW (1968) Retinopathy of Waldenström's macroglobulinaemia: photographic assessment. Am J Ophthalmol 65: 696-706

8. Clarke SW (1966) Myelomatosis meningitis and eye changes. Proc R Soc Med 59: 423

9. Ashton N (1951) Retinal micro-aneurysms in the nondiabetic diabetic subject. Br J Ophthalmol 35: 189-212

10. Paisey RB, Bradshaw P, Hartog M, West P (1979) Home monitoring of blood glucose using filter paper strips. $\mathrm{Br}$ Med J II: 1509 (letter)

11. Weed RI, La Celle PL, Merrill EW (1969) Metabolic dependence of red cell deformability. J Clin Invest 48: 795-809

12. Walburn FJ, Schneck DJ (1976) A constitutive equation for whole human blood, Biorheology 13: 201-210

13. Easthope P, Brooks DE (1979) A comparison of constitutive functions for whole human blood. Microvasc Res 17: 110

14. Dintenfass L (1978) Hyperviscosity in disease. Lancet I: 327-328

15. Jonsson A, Wales JK (1976) Blood glycoprotein levels in diabetes mellitus. Diabetologia 12: 245-250
16. Yue K, Morris K, McLennan S, Turtle JR (1980) Glycosylation of plasma protein and its relation to glycosylated hemoglobin in diabetes. Diabetes 29: 296-300

17. Schmid-Schonbein $H$, Volger $E$ (1976) Red-cell aggregation and red-cell deformability in diabetes. Diabetes 25 (Suppl 2): 897-902

18. Barnes A, Locke P, Dormandy J, Dormandy T (1977) Abnormal haemorheology in diabetes mellitus. Bibl Anat 16: 428-429

19. Mausolf FA, Mersher JH (1973) Experimental hyperviscosity and retinopathy: preliminary report. Ann Ophthalmol 5: 205-209

20. Jarrett RJ, Keen H (1976) Hyperglycaemia and diabetes mellitus. Lancet II : 1009-1012

21. Lowe GDO, Lowe JM, Drummond MM, Reith S, Belch JJF, Kesson CM, Wylie A, Foulds WS, Forbes CD, MacCuish AC, Manderson WG (1980) Blood viscosity in young male diabetics with and without retinopathy. Diabetologia 18: 359-363

Received: October 9, 1979, and in revised form: May 30, 1980

Dr. R. B. Paisey

Department of Medicine

Bristol Royal Infirmary

Old Building

Bristol

England 